Apidologie, 1984, 15 (2), 223-231

\title{
SEASONAL EFFECTS ON ARTIFICIAL INSEMINATION OF HONEYBEE QUEENS (APIS MELLIFERA L.)
}

\author{
Robin F.A. MORITZ and M. KÜHNERT \\ Institut für Bienenkunde (Polytechn. Ges.) \\ J.W. Goethe Universität Frankfurt/M. \\ Kall-von-Frisch-Weg 2, D 6370 Oberursel/Ts \\ West Germany
}

\begin{abstract}
SUMMARY
In a long term study from 1972-1983 in West Germany the success of artificial insemination of 3440 queen honeybees was protocolled. Strong seasonal effects on the insemination success could be found. The frequency of queen losses after emergence and insemination increased with the proceeding season. $92.3 \%$ of all inseminated queens successfully started oviposition. The onset of oviposition after artificial insemination or double $\mathrm{CO}_{2}$ narcosis was delayed in the late season (from 5.7 in April to 14.3 days in September). The frequency of drone laying queens after insemination showed no significant correlation to seasonal effects and was less than $2 \%$ at the average.
\end{abstract}

\section{INTRODUCTION}

Artificial insemination (A.I.) of honeybee queens (Apis mellifera) became an important routine method in honeybee breeding after its first presentation by Watson $(1927,1929)$, Nolan (1932). The technique got first practical use by the work of MACKensen (1947) and MaCKensen and Roberts (1948). At least since the publications of RUTTNER $(1969,1976)$ and MACKENSEN and TUCKER (1970) instrumental insemination became accessable at large scale for practical queen and bee breeders world wide.

The advantage of A.I. for breeding purposes is obvious. On natural mating flights honeybee queens mate with several drones of unknown genotype (TABER 
and Wendel, 1958 ; WoYke, 1960, Adams et al., 1977). Artificially inseminated queens ensure truly controlled matings. Therefore the genetic progress in selection programs with honeybees can be obtained much faster than with natural matings. A.I. supplies a method which gives more exact estimates of the basic quantitative genetical parameters in honeybee breeding (RINDERER, 1974; OLDROYD and Moran, 1983 ; Moritz, 1984 b). Especially the advanced centrifugation technique becomes an increasing importance for estimating genetic variances and heritabilities in honeybee populations. With this method single queens can be inseminated by a homogenous mixed semen sample of a large number of drones (e.g. more than 100) (Kaftanoglu and Peng, 1980 ; Moritz, 1983, 1984 a).

Also for basic scientific biological problems A.I. is a very important tool and has been used for various purposes. Keeping mutant lines, selecting behavioural strains, testing maternal effects and producing inbred lines is only possible with a method that ensures controlled matings.

In spite of this great importance of A.I., there are still several open questions concerning the physiological and biological factors affecting the honeybee queen during the procedure. Even with a highly standardized insemination technique environmental effects have a strong influence on the insemination success (FresnaYe, 1966). In this paper we report on seasonal effects on the efficiency of artificial insemination, which may be of high importance especially for commercial queen breeders.

\section{METHODS}

In a long term study over 11 years (1972-1983) at the Institut für Bienenkunde in Oberursel (West Germany) the fate of 3440 artificially inseminated honeybee queens was protocolled. The queens were reared with standard methods according to RutTnER $(1978,1980)$. The virgin queens were kept in mating nuclei (apx. 2500 bees) with queen excluders at the hive entrance to prevent natural matings. At the age of five days the queens were clipped at the left wing, marked with a colour dot on the thorax, caged and narcotizised for $10 \mathrm{~min}$ with $\mathrm{CO}_{2}$. Two days later the queens were inseminated with $8 \mu \mathrm{l}$ undiluted semen under a second $\mathrm{CO}_{z}$ narcosis (5 $\mathrm{min}$ ). An insemination device according to RutrNer (1976) with a glass tip syringe was used. Hyes solution $\left(0.9 \% \mathrm{NaCl} ; 0.02 \% \mathrm{CaCl} ; 0.02 \% \mathrm{KCl} ; 0.01 \% \mathrm{NaHCO}_{3}\right.$; in distilled water with $0.1 \mathrm{M}$ PenicillinG-sodium and 0.1 Dihydrostreptomycin, $\mathrm{pH} \mathrm{8.5)} \mathrm{was} \mathrm{used} \mathrm{as} \mathrm{semen} \mathrm{stopper} \mathrm{fluid} \mathrm{in} \mathrm{the} \mathrm{insemination}$ syringe. After the insemination of the queens, the colonies were controlled weekly. The age of the first brood was estimated in order to determine the day of first oviposition of the queens. The controls were continued at least until emergence of the first brood. Time between emergence, first $\mathrm{CO}_{2}$ narcosis, insemination, day of first oviposition (drone or worker brood) and queen loss was determined with help of a BASIC catalogue program on a micro computer (HP 9826, $356 \mathrm{kB}$ RAM). 


\section{RESULTS}

Fig. 1 shows the frequency of queen losses between the according control intervals. More than half of all queen losses are before A.I. Once the queen is laying eggs the frequency of queenless colonies becomes less than $2 \%$ of the total number of laying queens. Also between the first $\mathrm{CO}$.2 narcosis and insemination queen losses are rare $\left(2.7 \%\right.$ of all queens which got the 1 st $\mathrm{CO}_{2}$ treatment). Obviously the first week after emergence and the time between insemination and first oviposition are most critical for the queens. More than $80 \%$ of all queen losses occured in this period.

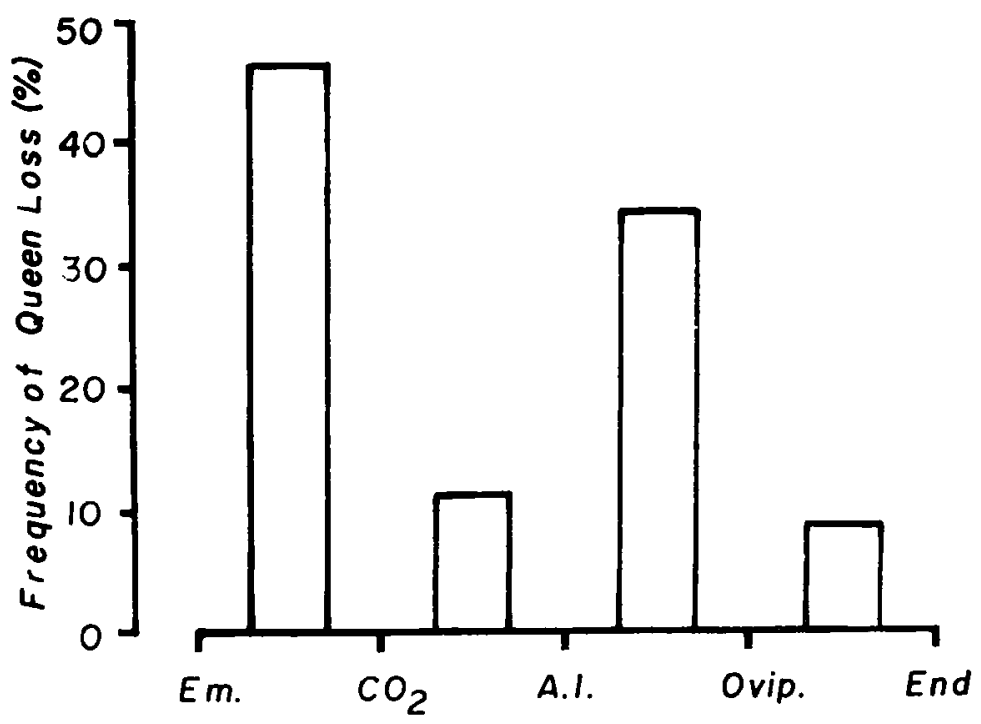

Fig. 1. - Percentage of total queen losses $(n=857)$ between emergence (Em.), $\left(\mathrm{CO}_{2}\right)$, artificial insemination (A.I.), oviposition (Ovip.) and end of observation period (End; usually when first aduh offspring emerges).

The risk of loosing a queen is not constant troughout the season. Fig. 2 shows that in early season the probability of queen losses after emergence, insemination and oviposition is smaller than later in the season. The non parametric procedure of Spearman results in a significant correlation between time of year and frequency of queenloss for all cases. 

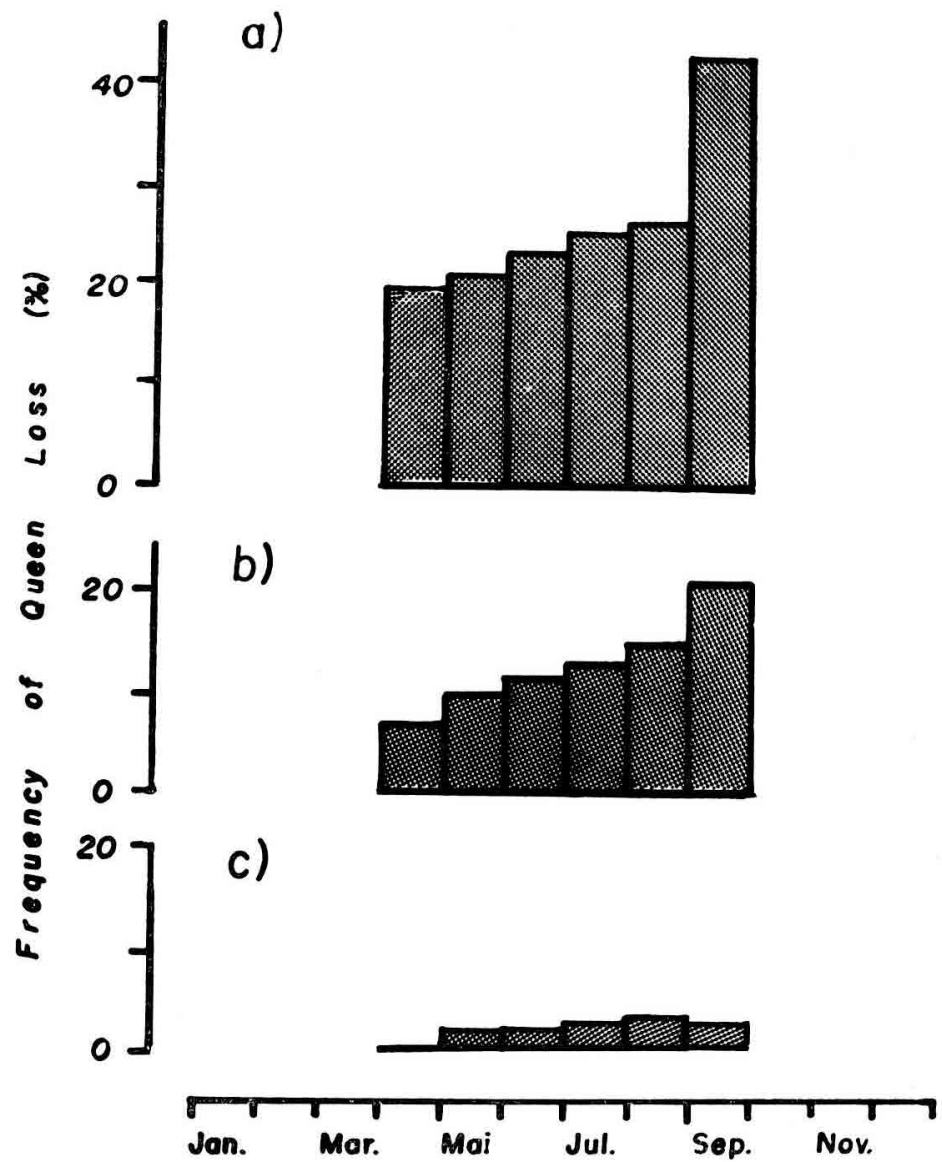

FIG, 2. - Frequency of queen losses after emergence $(a ; n=3440)$, artificial insemination ( $b ; n=2675)$ and oviposition ( $c ; n=2154)$.

For each month (x-axis) the values of 11 years are pooled. There is a significant increase for all three bar graphs with the proceeding time of year [Spearman's test : a) and b) $r_{s}=1$, $\mathrm{p} \leq 0.05 ;$ c) $\left.\mathrm{r}_{\mathrm{s}}=0.96, \mathrm{p}=0.05\right]$.

There was no significant seasonal effect on the frequency of drone layers after A.I. in our study. The overall frequency is very low (less than $2 \%$ of all artificially inseminated queens) (Fig. 3). 


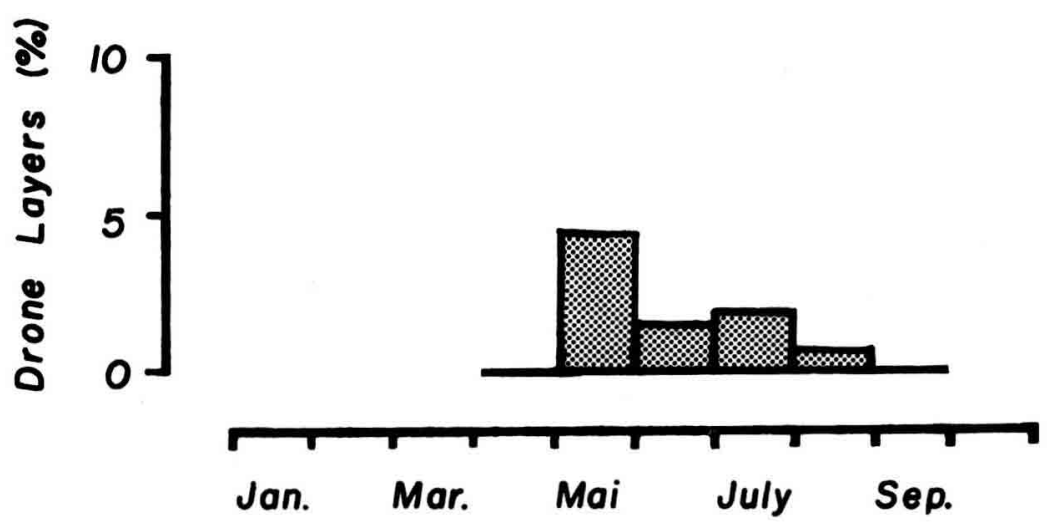

Fig. 3. - Frequency of drone laying queens after artificial insemination.

There is no signficant correlation to seasonal effects $\left(r_{s}=0.7 ;\right.$ n.s. $)$.

The start of oviposition after A.I. is strongly affected by seasonal changes (Fig. 4). Early in the season artificial inseminated queens start laying eggs very soon after A.I. ( $5.7 \pm 0.25$ days). This time increases with the procecding season. In september queens started laying $14.3 \pm 0.85$ days after insemination.

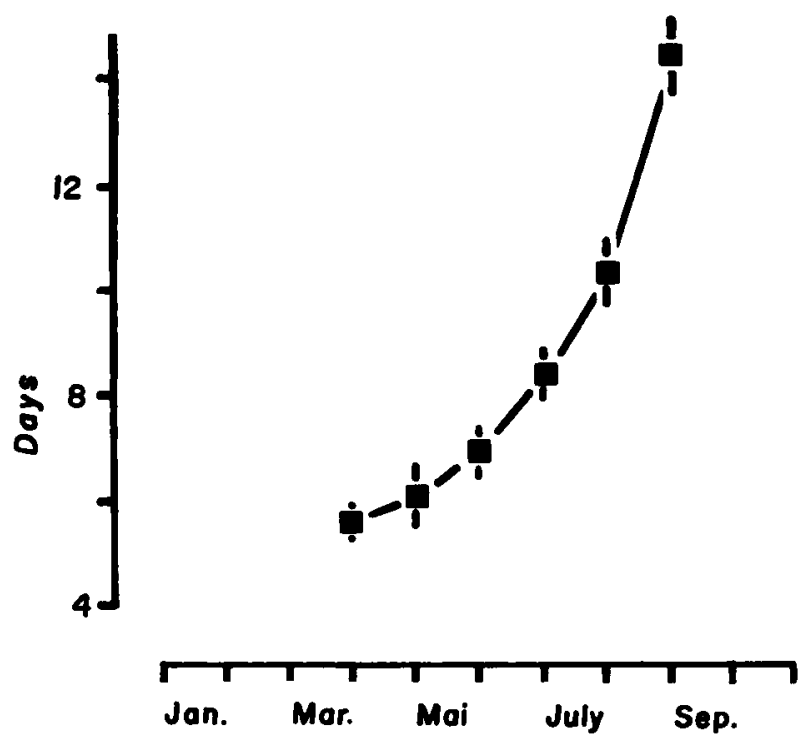

FIG. 4. - Time (means \pm s.e. in days)

between artificial insemination and initial oviposition of honeybee queens $(n=2675)$.

There is a significant increase of the time interval the later the season (slope different from zero, t-test : $\mathrm{t}=7.67, \mathrm{p} \leq 0.05$ ). 
36 out of the tested queens were not inseminated but got a second $\mathrm{CO}_{2}$ narcosis instead. These queens were used for drone production. In general the same phenomenon as after regular insemination was observed. The beginning of oviposition was delayed the later the season from 6.2 days in May to 8.4 days in July (Fig. 5). The total average time between second $\mathrm{CO}_{2}$ treatment and oviposition is not different to regular inseminated queens and to those queens which became drone layers after artificial insemination.

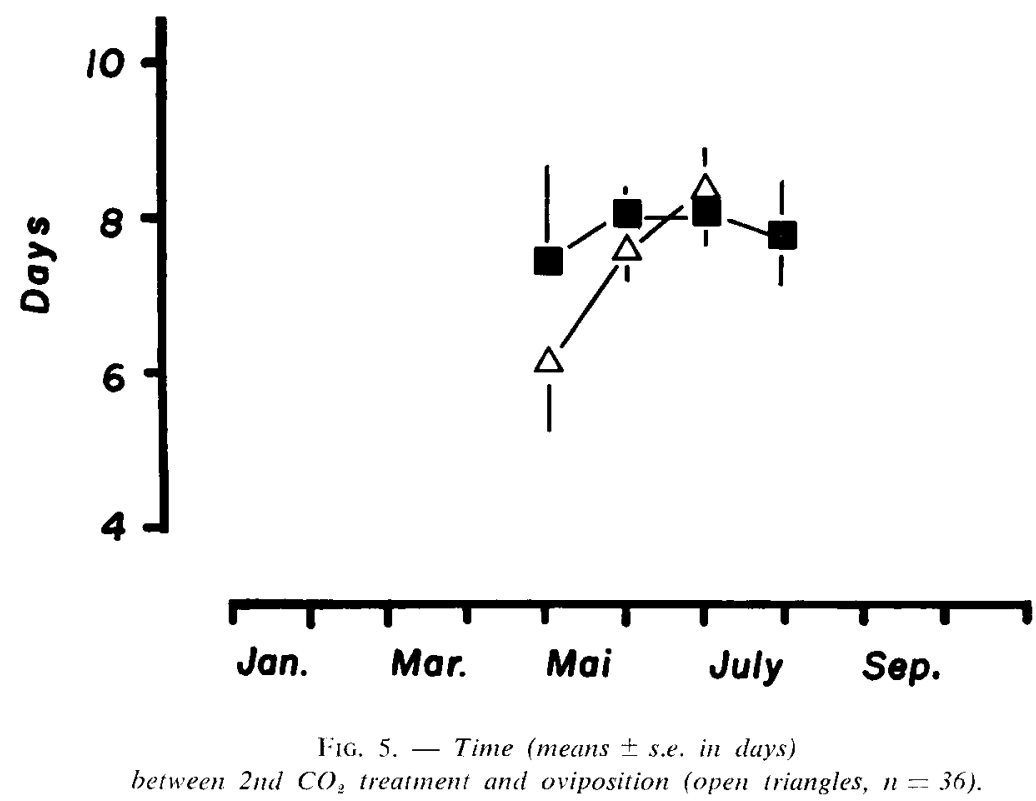
$(n=49)$.

The squares show the time between insemination and initial oviposition of drone laying queens

\section{DISCUSSION}

Our results show that seasonal changes in the natural environment are an important factor for the success of A.I. For most tested parameters the best results were obtained early in the season, which is late April to early May under the climate conditions of Western Europe. The probability of queen losses is small and there is only a brief interval between insemination and onset of oviposition. The average time of all tested queens was $7.67 \pm 0.07$ days, which is similar to observations made by other authors. MACKENSEN (1947) showed that queens getting a double, three- or four fold $\mathrm{CO}_{2}$ narcosis start oviposition at an average age of 15 days after emergence when they were inseminated at ages ranging from 2 to 9 days. In succeeding experiments he obtained an average initial oviposition age of 
11.5 days, 5.3 days after completion of the second $\mathrm{CO}_{2.2}$ treatment. Kaftanoglu and PENG (1980) found $7.8 \pm 1.9$ days between A.I. and first oviposition using the method according to MACKENSEN and TUCKER (1970) with Kiev semen diluent and a double $\mathrm{CO}_{2}$ treatment. They used a three fold $\mathrm{CO}_{2}$ narcosis in a subsequent study (Kaftanoglu and Peng, 1982) and obtained similar time intervals as in their previous study. There is also no delay in initial oviposition in the centrifugation technique as reported by Kaftanoglu and Peng $(1980,1982)$ as long as appropriate semen diluents are used. The time till onset of oviposition can be even smaller than in the classical insemination technique (MoRITz, $1984 \mathrm{a}$ ).

The relative number of queen losses due to artificial insemination in our approach was small compared to other studies. At the overall average (in 11 years!) only $8.7 \%$ of all artificially inseminated queens did not start oviposition. MACKENSEN (1947) found $80 \%$ laying queens after insemination. WOYKE and RUTTNER (1976) reported of $19.8 \%$ losses after A.I. in a two years study including 2587 queens. Kaftanoglu and Peng $(1980,1982)$ obtained an average loss of $12.2 \%$ after inseminations early in the season. The low risk for queen losses in our study may be due to the highly standardized technique in insemination and queen maintenance.

In spite of the good insemination results in the early season, there may rise problems in drone rearing at that time. The main drone production starts May in and large numbers of fertile drones are usually not available before June under the climate conditions of Western Europe. The high number of drone laying queens in May (Fig. 3) could be partially caused by this problem. The lack of fertile drones may have lead to inseminations of queens with infertile semen of too young drones. Consequently these queens lay unfertilized eggs and produce drone offspring. The lack of drones may also cause a delay of the insemination date, which results in a long time between emergence and insemination. This is important especially for practical queen breeders. The time they have to maintain the queen in the mating nuce increases which will rise additional costs. Early drone production by $\mathrm{CO}_{2}$ narcotizised drone laying queens also is a costly procedure. Hence, for applied purposes, the best time for inseminations seems to be the mid of the season, in spite of a not maximal success of A.I. at that time.

Received for publication in April 1984.

\section{ACKNOWLEDGEMENT}

We are grateful to our teacher Prof. Dr. Dr. F. Rutrnes to whom this paper is dedicated. He introduced us into the technique of instrumental insemination of honeybee queens. His great engagement on this field made the present study possible. Most of the presented results (1972-1980) were produced under his directory as head of the Institut für Bienenkunde in Oberursel. We also wish to thank Mr. W. Görz and Mr. W. Würkner for providing the bee material. We thank Prof. Dr. E.E. Southwick for proof reading of the manuscript. 


\section{RÉSUME \\ INFLUENCE DE LA SAISON SUR L'INSEMINATION ARTIFICIELLE DES REINES D'ABEILLE (APIS MELLIFICA L.)}

Au cours d'une étude de longue haleine portant sur 11 ans (1972-1983) à l'Institut für Bienenkunde à Oberursel (RFA) on a étudié l'influence des saisons sur les résultats de l'insémination des reines d'abeilles (Apis mellifica L.). On a réuni des données portant sur 3440 reines. Les reines ont été élevées selon la méthode standard (voir RuTrNer, 1980) et maintenues en ruchettes de fécondation (2500 abeilles). A l'âge de 5 jours les reines ont subi une $1^{\text {ro }}$ anesthésie au $\mathrm{CO}_{2}(10 \mathrm{~min})$. Deux jours plus tard a eu lieu l'insémination, selon la méthode de RuTTNER (1976), sous une $2^{\mathrm{e}}$ anesthésie au $\mathrm{CO}_{2}$. On a noté pour chaque reine le $1^{\text {er }}$ jour de ponte et le sexe du couvain produit.

L'étude montre que le risque de perte de reines est plus élevé avant l'insémination qu'après (Fig. 1). A la fin de la saison les pertes de reines sont plus fréquentes, que ce soit avant ou après l'insémination (Fig. 2). Le laps de temps entre l'insémination, ou la double narcose, et le début de la ponte augmente lorsqu'on avance en saison (Fig. 4 et 5). On n'a trouvé aucune influence saisonnière continue quant à la probabilité d'apparition de reines bourdonneuses (Fig. 3).

Le meilleur résultat dans l'insémination artificielle est manifestement obtenu en début de saison. Il faut tenir compte du problème de l'élevage des mâles dans le choix de dates d'insémination plus précoces. L'élevage de mâles fertiles à l'aide de reines bourdonneuses au début du printemps représente un risque économique élevé. Pour l'éleveur professionnel, la production principale de reines inséminées doit donc avoir lieu en milieu de saison, bien que les résultats de l'insémination soient meilleurs au printemps.

\section{ZUSAMMENFASSUNG}

\section{SAISONALE EFFEKTE BEI DER INSTRUMENTELLEN BESAMUNG DER BIENENKÖNIGIN (APIS MELLIFERA L.)}

In einer Langzeitstudie über 11 Jahre (1972-1983) am Institut für Bienenkunde, Oberursel (BRD) wurde der Einfluß saisonaler Effekte auf den Besamungserfolg bei der Königin der Honigbiene (Apis mellifera L.) untersucht. Insgesamt wurden Daten von 3440 Königinnen erfaßt. Die Königinnen wurden nach Standardmethoden (siehe RUTTNER, 1980) gezogen und in Begattungsvölkchen (2 500 Bienen) gehalten. Im Alter von 5 Tagen erhielten die Königinnen eine erste $\mathrm{CO}_{2}$ Narkose (10 min). Zwei Tage später erfolgte die Besamung nach Rutrner (1976) unter einer zweiten $\mathrm{CO}_{2} \mathrm{Narkose}$ Von jeder Königin wurde der Tag der ersten Eilage und das Geschlecht der erzeugten Brut bestimmt.

Es zeigte sich, daß das Risiko eines Königinnenverlusts vor der Besamung größer war als danach (Abb. 1.). Zum Saison-Ende hin steigt die Häufigkeit für Königinnenverluste sowohl vor als auch nach der Besamung an (Abb. 2). Die Zeit bis zum Beginn der Eilage nach der künstlichen Besamung sowie nach doppelter $\mathrm{CO}_{2}$ Narkose nimmt ebenfalls im Laufe der Saison zu (Abb. 4 und 5). Für die Wahrscheinlichkeit drohnenbrütiger Königinnen konnte kein kontinuierlicher saisonaler Einfluß gefunden werden (Abb. 3).

Offensichtlich wird das beste Resultat in der künstlichen Besamung am Saisonanfang erzielt. Allerdings müssen bei frühen Besamungsterminen Probleme in der Drohnenaufzucht berücksichtigt werden. Die Aufzucht von fertilen Drohnen mit Hilfe drohnenbrütiger Königinnen im zeitigen Frühjahr (März, April) stellt ein hohes Kostenrisiko dar. Für den kommerziellen Züchter sollte daher die Hauptproduktion besamter Königinnen in die Saisonmitte fallen, trotz der besseren Besamungserfolge im Frühjahr. 


\section{LITERATURE}

Adams J., Rothman E.D., KerR W.E., Paulino Z.L., 1977. - Estimation of the number of sex allels and queen matings from diploid male frequencies of Apis mellifera. Genetics, 86, 583-596.

Fresnaye J., 1966. - Influence des variations de lâge de maturité sexuelle chez les reines d'abeilles (Apis mellifica mellifica), fécondées par insémination artificielle. Ann. Abeille, 9, 237-242.

Kaftanogi.u O., Peng Y.-S., 1980. - A washing technique for collecting honeybee semen. J. apic. Res., 19. $205-211$.

Kaftanoglu O., Peng Y.-S., 1982. - Effects of insemination on the initiation of oviposition in the queen honeybee. J. apic. Res., 21, 2-6.

Mackensen O., 1947. - Effect of carbon dioxide on initial oviposition of artificially inseminated and virgin queen bees. J. econ. Entomol., 40, 344-349.

MACKENSEN O., ROBER'TS W.C., 1948. - A manual for the artificial insemination of queen bees. U.S.D.A., Bur. Ent. Plant Quart. ET-250.

Mackensen O., Tucker K.W., 1970. - Instrumental insemination of queen bees. USDA., Agric. Handbook, 390.

MORITZ R.F.A., 1983. - Homogenous mixing of honeybee semen by centrifugation. J. apic. Res., 22, 249-255.

Moritz R.F.A., 1984 a. - The effect of different diluents on the insemination success in the honeybee (Apis mellifera) using mixed semen. J. apic. Res., 23, in press.

Moritz R.F.A. 1984 b, - Selection in small populations of the honeybec (Apis mellifera L.). Z. Tierzücht. Züchtungsbiol., in press.

NolaN W.J., 1932. - Breeding the honeybee under controlled conditions. U.S.D.A. Tech. Bull., 326.

Oidroyo B., Moran C., 1983. - Heritabilities of worker characters in the honeybee (Apis mellifera). Alust. J. Biol. Sci., 36, 323-332.

Rinderer T.D., 1974. - Measuring the heritability of characters of honeybees. J. Apic. Res., 16, 95-98.

Ruttner F., 1969. - Die instrumentelle Besamung der Bienenkönigin. Apimondia Publishing House, Bucharest.

Rutrner F., 1976. - The instrumental insemination of the queen bee. Apimondia Publishing House, Bucharest.

RuttNer F., 1978. - Zuchttechnik und Zuchtauslese bei der Honigbiene. Ehrenwirth, Munich.

Ruttner F., 1980. - Königinnenzucht. Apimondia Publishing House, Bucharest.

Taber S., Wendel J., 1958. - Concerning the number of times queen bees mate. J. Econ. Entomol,, 51, 786-789.

Watson L.R., 1927. - Controlled mating in the honeybee. Rep. Sta. Apiarist, Iowa, 36-41.

WATSON L.R., 1929. - New contributions to the technique of instrumental insemination of queen bees. J. Econ. Entomol., 22, 944-954.

Woyke J., 1960. - Naturalne i sztuczne unasienianie matek pszczelich. Pszczel. Zes. Nauk. 4, $183-273$.

WOyke J., Ruttner F., 1976. - Results. In Instrumental insemination of the queen bee. Ed. : Ruttner F., Apimondia Publishing House, Bucharest, p. 87-92. 